\title{
Contents of Journals relating to the Journal of Vocational Rehabilitation
}

\section{Journal of Back and Musculoskeletal Rehabilitation, Vol. 6, No. 1, January 1996}

\section{From the Editor}

K. Rucker

Introduction

R.P. Wilder, F. O'Connor

Overuse injuries of the hip and pelvis

M.C. Geraci, Jr. (USA)

Special considerations for the pediatric running population

C.W. Zukowski, W.A. Lillegard (USA)

Special considerations for the female runner

C.M. Fieseler (USA)

Cross-training and periodization in running

D.K. Brennan, R.P. Wilder (USA)

Distance running: Organization of a medical team

J.C. Cianca (USA)

Running shoes and orthoses: a practical approach

J.A. Johnson (USA)

Appendix 1

Announcement

Instructions to Authors

NeuroRehabilitation, Vol. 6, No. 2, April 1996

Introduction

J.D. Banja (USA)

Interdisciplinary team member perceptions of ethical issues in traumatic brain injury rehabilitation

V.M. Tarvydas, L. Shaw (USA)

Ethical issues in the evaluation of competence in persons with acquired brain injuries

M. Rosenthal, I. Lourie (USA)

Assessing client competence to participate in rehabilitation decision making

V.S. Auerbach, J.D. Banja (USA) 
The role of an ethics committee in a rehabilitation setting

R.T. Guenther, L.J. Weber (USA)

The Americans with Disabilities Act: An ethical perspective as the law develops

W. Wilkinson, C. Dresden (USA)

Upcoming conference

\section{Work, Vol. 6, No. 3, May 1996}

\section{From the Editor}

Multiple sclerosis: Etiology, incidence and prevalence

P.D. Rumrill, Jr., J.C. Battersby, D.A. Kaleta (USA)

Health status, work impediments, and coping related to work roles of women with multiple sclerosis

E.E. Gulick (USA)

Job placement interventions for people with multiple sclerosis

P.D. Rumrill, Jr., J.M. Steffen, D.A. Kaleta, C.A. Holman (USA)

Factors associated with unemployment among persons with multiple sclerosis

P.D. Rumrill (USA)

Job retention interventions for persons with multiple sclerosis

P.D. Rumrill, J.M. Steffen, G. Sumner (USA)

The role of assessment in enhancing the vocational success of people with multiple sclerosis R.T. Roessler (USA)

Goal oriented inpatient multiple sclerosis group

C. Laporte (USA)

Employment and multiple sclerosis: Policy, programming, and research recommendations P.D. Rumrill (USA)

Book review

Author index

Subject index

Volume contents 